Part 1.

Studia Iuridica Lublinensia vol. XXVII, 1, 2018

DOI: $10.17951 /$ sil.2018.27.1.27

\author{
Bojan Spaić \\ University of Belgrade, Serbia \\ bojan.spaic@ius.bg.ac.rs
}

\title{
The Authority of Precedents in Civil Law Systems ${ }^{1}$
}

\author{
Autorytet precedensu w systemach prawnych civil law
}

\begin{abstract}
SUMMARY
In this paper, precedents are analysed in terms of reasons that they can give to judges in various legal systems, with the purpose of identifying the ways in which precedents can be authoritative in judicial reasoning. The analysis starts with the distinction between two kinds of precedents - precedents of solution and precedents of interpretation. The ways in which both precedents of solution and precedents of interpretation affect the reasoning of future courts are identified and described, in order to focus on instances in which this affection can be considered practically and epistemically authoritative. Finally, conditions for considering under which it can be justified to treat precedents as authoritative are laid down, with a special emphasis on the possibility of justifying the epistemic authority of interpretative precedents.
\end{abstract} authority

Keywords: precedent; authority of precedents; precedential practice; epistemic authority; practical

[W]e do not write on a clean slate ${ }^{2}$.

${ }^{1}$ I'm grateful to Ken Himma for insightful and detailed comments on the draft of the paper, as well as to participants in the workshop Potential of Precedent in the Statutory Legal Order. Context of Political and Legal Discourse, organized by Leszek Leszczyński and Adam Szot as a part of the "XXVIII World Congress of the International Association for the Philosophy of Law and Social Philosophy" (IVR). The opportunity for engaging the topic of the paper was provided by the Alexander von Humboldt Foundation scholarship for research on the Institute for public law, constitutional law and philosophy of law under the supervision of Martin Borowski. This paper is a result of the work on the University of Belgrade Faculty of Law project "Transformation of Identity of Serbia" in 2018.

${ }^{2}$ Miller v. Fenton et al. 474 U.S. 104 (1985). The quote and the judgement figure prominently in the paper on precedents by Gerald Postema. See: G.J. Postema, On the Moral Presence of Our Past, "McGill Law Journal” 1991, Vol. 36(4), pp. 1153-1221. 


\section{REASONING WITH PRECEDENTS}

There are at least two ways in which we talk about precedents in legal theory and philosophy. Sometimes, in what is thought to be technical legal usage of the term, we say that precedents are judicial decisions that either establish or exemplify a norm of conduct that is binding for courts in future cases. Other times, we use the word 'precedent' to denote any past decision that is in any way, covertly or overtly, used to decide similar issues in the present and future cases.

When we refer to precedents in the first, technical, sense of the word we are commonly talking about the idea of formal sources of law and the doctrine of stare decisis. From a civil-law perspective, we are, in general terms describing the fact that for the most part, in civil-law legal systems, previous judicial decisions are not, as a matter of law, binding for future judicial decisions ${ }^{3}$. We then contrast this tradition with the common law tradition in which the precedents are binding as a matter of law.

While it might be argued that this rough picture that relies on a crude notion of sources of law, and a reductive view about precedents, this very picture is quite dominant in continental legal theory. And indeed, it reflects an important insight about the authority of precedents in common law systems - being formal sources of law precedents are not simply illustrative, but actually, bind the authoritative legal interpreters on future occasions.

Already at the end of the last century, a major study of the role of precedents in legal systems convincingly concluded that "precedent now plays a significant part in legal decision making and in the development of law [...] whether or not precedent is officially recognized as formally binding"4. In fact, many constitutions nowadays contain explicit norms that prescribe previous judicial decisions as sources of law, which makes precedents formally binding in civil-law systems. Insofar as it is still common to claim that precedents are most often thought to have persuasive strength at best, and not legal authority ${ }^{5}$, the common claim is wrong ${ }^{6}$.

3 This makes even talking about precedent in a nontechnical fashion quite problematic. The very mentioning of the word "precedent" in the context of civil law systems, often provokes an unreasonable negative reaction. Given the strong tendency toward the idea that legislative bodies are the sole creators of law, this attitude is somewhat understandable, but definitely not justifiable.

${ }^{4}$ N. MacCormick, R.S. Summers, Further General Reflections and Conclusions, [in:] Interpreting Precedents, eds. N. MacCormick, R.S. Summers, Routledge, 1997, pp. 531-532.

${ }^{5}$ N. Duxbury, The Nature and Authority of Precedent, Oxford University Press, 2010, p. 13.

${ }^{6}$ Or, as Anthony Kronman writes: "Respect for past decisions, for precedent, is not a characteristic of certain legal systems only. It is rather a feature of law in general, and wherever there exists a set of practices and institutions that we believe are entitled to the name of law, the rule of precedent will be at work, influencing, to one degree or another, the conduct of those responsible for administering the practices and institutions in question”. See: A.T. Kronman, Precedent and Tradition, "The Yale Law Journal" 1990, Vol. 99, DOI: https://doi.org/10.2307/796595, p. 1032. We 
This reductive use of the term "precedent" to refer just to formally binding judicial decisions is somewhat unjustified. Basing an instance of reasoning on a previous instance of reasoning in a same or similar is not a specificity of legal reasoning. We often treat our previous behaviours as reasons for acting the same way in the same situations in the future ${ }^{7}$. In common parlance, and in most of the common law legal theory and philosophy of law, the word 'precedent' is taken to mean "something done or said that may serve as an example or rule to authorize or justify a subsequent act of the same or an analogous kind" or "the convention established by such a precedent or by long practice" .

This dictionary definition can be, and often is, framed with more precision. First of all, the common definition implies that reasoning with precedents is not a form of reasoning confined to courts and other state officials. Every time that we make a claim that we have a reason for deciding $X$ in the case $A$, because $X$ was decided when A occurred previously, we are in fact reasoning with precedents. To say that we acted in the way $\mathrm{X}$ in the situation $\mathrm{A}$, because we did so previously, is to say that the previous act gives us a reason for acting now ${ }^{9}$. Quite obviously, this form of reasoning is not confined to common-law courts but is a significant part of legal reasoning of any court. In this common sense of the word, precedents are considered to be simply "prior decisions that serve as a model for future decisions"10. From this perspective, the technical meaning of the word 'precedent' is just a special case of the common meaning of the word 'precedent'. In fact, having a system of law in which precedents are formal sources of law amounts to the fact that judges are obligated to decide $\mathrm{X}$ in cases $\mathrm{A}$, because of earlier decisions $\mathrm{X}$ in the case $\mathrm{A}$. In other words, in those systems precedents give judges legal reasons to decide cases.

Both meanings of the word 'precedent' give rise to interesting and important issues in theory and philosophy of law. In this paper I'll, however, be primarily concerned with framing the role of precedents in terms of reasons that they can give to judges in various legal systems. The main purpose of this paper is to identify the ways in which precedents can be authoritative in judicial reasoning. First, I'll explain the distinction between two kinds of precedents - precedents of solution and precedents of interpretation. Second, I'll identify the ways in which both pre-

could still, of course, hold the view that the use of precedents in civil-law countries is not justified from a certain point of view.

7 Frederick Schauer notes that "reliance on precedent is part of life in general". See: F. Schauer, Precedent, "Stanford Law Review" 1987, Vol. 39(3), DOI: https://doi.org/10.2307/1228760, p. 571.

${ }^{8}$ Merriam-Webster Dictionary, www.merriam-webster.com/dictionary/precedent [access: 10.02.2018]. Larry Alexander calls this intuitive idea that previous decisions are naturally given a weight in present reasoning "the natural model of precedent". See: L. Alexander, Constrained by Precedent, "Southern California Law Review" 1989, Vol. 63(1), p. 5.

${ }^{9}$ F. Schauer, Precedent, p. 571.

${ }^{10}$ N. MacCormick, R.S. Summers, Introduction, [in:] Interpreting Precedents, p. 1. 
cedents of solution and precedents of interpretation affect the reasoning of future courts, and focus on the cases in which this affection can be considered practically and epistemically authoritative. Finally, I'll consider the conditions under which it can be epistemically justified to treat precedents as authoritative, with an emphasis on the possibility of justifying the epistemic authority of interpretative precedents.

\section{PRECEDENTS OF SOLUTION AND PRECEDENTS OF INTERPRETATION}

The decision-making process of courts is not confined to deciding the case at hand, but also involves deciding issues of interpretation of texts and qualification of facts. Whenever a multiplicity of meanings can be ascribed to a legal text the task of adjudicative interpretation is to reach a decision about the meaning of the legal text. Adjudicating officials are supposed to settle the interpretative question; they are expected to ascribe a definite meaning to the legal text. Serving as a model could then mean at least two things that are relevant for our present purposes:

1. The facts of a case under litigation could be the same or similar in important ways ${ }^{11}$ with the facts of a case that was already decided. If the former obtains in a legal system in which precedents are formal sources of law ${ }^{12}$, a previous judicial decision serves as a model in the sense that it obligates the court to solve the case in question according to the precedent. In a long tradition of thinking about precedents common law theoretical and practical jurisprudence commonly identifies the binding element of previous decisions calling it ratio decidendi and distinguishing it from orbiter dicta ${ }^{13}$. What is binding in a previous judicial decision that has the status of precedent is the rule of law that is being laid down or followed by the court setting the

11 The meaning of appropriate is of course subject to much contention. The word used in Serbian theoretical jurisprudence is "essentially similar". Robert S. Summers uses the term "appropriately similar". See: R.S. Summers, Departures from Precedents, [in:] Interpreting Precedents, p. 520.

12 There is a lot to be said about the idea of a source of law. A clarification of sources of law not resting on this formalist premise leaves more breading room for precedents. Alexander Peczenik talks about three kinds of legal sources: "must sources", "should sources" and "may sources". "Must sources" are formally or de iure binding. "Should sources" are the texts that a judge is to take into account in his reasoning but he is not obligated to do so. "May sources" are additional materials that judge may or may not use in his reasoning aimed at reaching the decision (see: A. Peczenik, Scientia Juris: Legal Doctrine as Knowledge of Law and as a Source of Law, Springer Publishing, 2005, pp. 16-17). From this perspective precedents in civil-law countries are most often either should sources or may sources of law. It will become clear later on that they are, in a certain sense, also must sources in many contemporary civil-law jurisdictions.

13 This view is however far from uncontroversial. Larry Alexander notes that "if one were to ask law students, lawyers, judges, or legal academics what following precedent entails, one would almost surely get a variety of inconsistent answers". See: L. Alexander, op. cit., p. 3. 
precedent. The other parts of the precedent can have a significant amount of persuasive quality, but they are often not considered formally binding ${ }^{14}$. Whenever we talk about precedent in civil law we tend to have in mind this common law model of precedents that I'll call "precedents of solution"15. In setting, precedents of solution courts lay down a rule of law, and their function is in significant ways legislative and creative.

2. When a previous decision is used in future decisions this doesn't necessarily have to do with similarity or sameness of facts that require a legal solution. General legal provisions do not solve cases. Courts, especially higher courts in contemporary legal systems, decide on the meaning of statutory words and provisions. Consequently, the previous judicial decision can serve as a model in the sense that we follow them in reaching interpretative decisions based on the similarity or sameness of statutory and constitutional texts that are employed in resolving the case. No matter the importance that we ascribe to courts in relation to the legislator, it is certain that solving cases necessarily requires some interpretative work on the part of the courts. Often, the result of the interpretative work is a decision about the meaning of a legal provision. If this is so, then previous judicial decisions lay down an interpretation of existing legal texts that is relevant for future cases in which the same statutory or constitutional terms or provisions are applied. When this is the case, the precedents are called "precedents of interpretation"16.

In both cases, previous decisions serve as models for future decisions. Precedents of solution are decisions about a case, and precedents of interpretation are decisions about the meaning of a word, a sentence or an entire provision of law. There are some significant differences between precedents of solution and precedents of interpretation. One of the main tasks that a court has in regards of adjudicative precedents is to establish the sameness or similarity of the case before him and the case that was authoritatively adjudicated. This analogical reasoning is

${ }^{14}$ It should be noted here that the notion of "formally binding" is somewhat imported from continental legal thinking to the Anglo-American legal systems. The fact is that the notion of a formally binding precedent isn't introduced in English law by statutory or constitutional proclamation, and there is significant uncertainty about when judges started feeling formally bound to follow precedents (see: N. Duxbury, op. cit., pp. 17-18). Bentham and Austin considered precedent to be simply a decision in a previous case, confined to that case. As such, they are simple instances or examples of the application of a previously existing rule, and not rule-setting (ibidem, pp. 17, 59).

${ }_{15}$ M. Troper, Ch. Grzegorczyk, Precedent in France, [in:] Interpreting Precedents, p. 126.

${ }_{16} \mathrm{Ibidem}$. It is quite interesting to note that precedents were treated in common law jurisdictions as "evidence of common learning" of the entirety of legal profession. In this sense, previous decisions were not considered binding as a matter of law, but were mostly regarded as beliefs and they eventually gave reasons for believing (N. Duxbury, op. cit., p. 32). 
problematic, and in practice difficult ${ }^{17}$. This is not so when it comes to interpretative precedents. The idea of interpretative precedent encompasses the identity of the text interpreted by a previous court and a present court. The process of reasoning with interpretative precedents doesn't necessarily imply an assessment of the similarity of facts and is consequently much simpler ${ }^{18}$. With this in mind, let us turn to an analysis of what can it mean to serve as a model in the cases of adjudicative and interpretative precedents.

\section{AUTHORITY OF PRECEDENTS}

\section{Serving as a model}

To serve as a model in the context of analysing precedents means that a previous decision of a court in a way affects a current decision of a court. Since previous decisions can affect future decisions in quite insignificant ways, to claim that something served as a model is to claim that the subject is affected by the decision in a significant manner ${ }^{19}$. The first mode in which the precedents could affect future decision is by way of coercion. Contemporary legal systems for the most part do not authorise the use of sanctions for not following precedents in the way in which, for example, they authorise sanctions for jaywalking. Furthermore, judges do not routinely or often comply with precedents for threat of deprivation, and coercion necessarily implies this exact threat. Coercion is thus not a candidate for analysing the power of precedents. The second mode in which the precedents could significantly affect current decisions is by way of influence. Influence doesn't imply a threat of deprivation but still leads to a change in agent's actions or beliefs. Precedents in both continental and common law systems can have and often do have significant

${ }^{17}$ One of the problems with precedents of solution it that they are basically, as Frederick Schauer puts it, considered a fallacy from the perspective of philosophy. See: F. Schauer, Profiles, probabilities, and stereotypes, Harvard University Press, 2003, p. 273.

18 This doesn't mean that the interpretative reasoning is simple under all possible theoretical and all imaginable practical conditions. With both precedents of interpretation and precedents of solution we could in fact say that a decision in a case or an ascription of meaning is an instantiation of a rule (that may or may not be existent prior to the decision). That is indeed the sense in which the term is often used in literature. It was noted earlier that in this paper we'll give more weight to the nontechnical meaning of the word precedent of interpretation. This common meaning implies that the interpretative decision about the meaning of a legal text that serves as "a model for a future interpretative decision" - it is a singular stipulation of meaning that "influences" future interpretative stipulations, or ascriptions of meaning. This basically means that precedents are understood as instantiations of rules, but in precedents as reasons for action or belief.

19 See: S. Lukes, Power, Palgrave Macmillan, 2005, DOI: https://doi.org/10.1007/978-0-23080257-5, p. 30. 
influence in judicial decision making. Still, influence doesn't seem well suited to explain the fact that precedents are binding, in a sense non-optional, for judges in both common law and civil law. When something is a source of law, it is not merely considered to be influential in the sense that it is important, but can be disposed of. If a precedent is considered to be a source of law, it seems necessary that it has authority. Authority as a mode of power implies compliance with a deontic proposition for reasons of accepting an affection as legitimate or reasonable from the perspective of its content or procedures that brought forward the decision ${ }^{20}$. In the rest of the paper, I'll mostly discuss the authority of precedents and not simply their influence or persuasive strength ${ }^{21}$.

\section{Authority}

The most influential conception of authority in law to date is the service conception proposed by Joseph Raz. According to him a proper account of authority should be able to explain the role of authoritative directives in our practical reasoning ${ }^{22}$. From the perspective of practical reasoning, authority can be defined as a property of an entity $X$ that enables (mostly verbal) behaviours of person $X$ to act as reasons ${ }^{23}$ for a person $Y^{24}$. We say that $X$ has authority if $X$ is able with verbal utterances to change $Y$ 's reasons for doing or believing something ${ }^{25}$. Authority is thus the ability to give rise to new reasons for action or belief or the ability to change reasons for action or belief ${ }^{26}$. We are inclined to say that something or someone is an authority if her expression is able to change our reasons for acting or believing, not in virtue of the content of the expression but in virtue of the source

20 Ibidem, pp. 21-22.

21 This is not to say that the notion of "persuasiveness" is not important for an analysis of precedents. Ronald Dworkin argued that we should distinguish between the "enactment force of the precedent" and the "gravitational force of the precedent" (see: R. Dworkin, Taking Rights Seriously, Harvard University Press, 1977, p. 111). In the part of this paper that explains the practical authority of precedents, I'll mostly be interested in what Dworkin calls enactment force, and in the part of the paper that explains epistemic authority of precedents, I'll be mostly interested in gravitational force of precedents. It is just to say that the topic will not be tackled in detail in this paper. Some of the contributions and debates about the idea of persuasive influence, and the confused idea of "persuasive authority" can be found in the following papers: H.P. Glenu, Persuasive Authority, "McGill Law Journal" 1987, Vol. 32(2), pp. 261-298; C. Flanders, Toward a Theory of Persuasive Authority, “Oklahoma Law Review” 2009, Vol. 62(1), pp. 55-88; F. Schauer, Authority and Authorities, "Virginia Law Review" 2008, Vol. 94, pp. 1193-1196.

22 J. Raz, The Authority of Law, Oxford University Press, 1979, p. 10.

23 Reasons being facts that "count in favor" of doing or believing something (see: A. Marmor, Social Conventions, Princeton University Press, 2009, DOI: https://doi.org/10.1515/9781400831654, p. 5).

24 J. Raz, The Authority of Law, p. 12.

25 Ibidem, p. 19.

26 Ibidem, p. 16. 
of the expression ${ }^{27}$. To frame it formally: $X$ is an authority if his utterance $p$ can change reasons for action or reasons for belief of $Y$ not in virtue of the content of $p$ but in virtue of $p$ being uttered by $X$.

With authority, we reach the idea of "serving as a model" that we are most interested in when it comes to precedents - a precedent has authority over judges if it gives them content-independent reasons. But what kind of reasons can a precedent give us? The distinction between various types of reasons in our practical reasoning, like reasons for desires, emotions, attitudes, norms, and institutions and so on, can in principle be condensed to two fundamental types - reasons for action and reasons for belief ${ }^{28}$. In light of this distinction, we distinguish two basic kinds of authority: practical and epistemic ${ }^{29}$. According to J. Raz, practical and epistemic authority have "the same basic structure", but that the main difference is that "they provide reasons for different things" ${ }^{130}$ - while practical authority gives reasons for action, epistemic authority gives reasons for belief ${ }^{31}$.

${ }^{27}$ F. Schauer, Authority... An important difference that Raz makes in this regard is the difference between having authority and being an authority. I could have the authority to use the scanner in my Institute without being an authority for anyone. The central case of authority is for Raz the authority over persons. See: J. Raz, The Authority of Law, pp. 20-21.

${ }^{28}$ Idem, Practical Reason and Norms, Oxford University Press, 1999, DOI: https://doi. org/10.1093/acprof:oso/9780198268345.001.0001, p. 15.

${ }^{29}$ H.M. Hurd, Moral Combat, Cambridge University Press, 1999, DOI: https://doi.org/10.1017/ CBO9780511896880, pp. 62-63. The literature on the authority of other persons and their opinions over oneself and his opinions varies significantly when it comes to naming the kind of authority that the authors analyse. Heidi Hurd takes epistemic authority to be a general term that includes advisory authority, influential authority and theoretical authority (ibidem, p. 63). Richard Foley tends to call this kind of authority intellectual authority (see: R. Foley, Intellectual Trust in Oneself and Others, Cambridge University Press, 2001, DOI: https://doi.org/10.1017/CBO9780511498923, p. 83). Raz is inclined to call it theoretical authority (see: J. Raz, The Authority of Law, p. 12; idem, The Morality of Freedom, Oxford University Press, 1988, DOI: https://doi.org/10.1093/0198248075.001.0001, p. 29), and Zagzebski uses the term epistemic authority (L.T. Zagzebski, Epistemic Authority, Oxford University Press, 2012).

30 J. Raz, The Morality of Freedom, p. 53. One kind of "authority" that is often mentioned but won't be a topic in this paper is called "persuasive authority". In a paper from 1987 H. Patrick Glenu notes that the concept lacks formal definition (see: H.P. Glenu, op. cit., p. 264), but still states somewhat metaphorically that it is "the authority which attracts adherence as opposed to obliging it" (ibidem, p. 263). Glenu's primary motive behind this "definition" of persuasive authority is to analyse the sources of law and to contrast sources of law that poses persuasive authority to those that have binding authority. But persuasive authority obviously has a problem. If an authority is conceptually characterized by the fact that it purports to provide content independent reasons for action, persuasion in this sense can never really be authoritative. A partial solution to this problem is proposed by Oran Doyle who claims that persuasive authority is essentially a theoretical authority. See: O. Doyle, Constitutional Cases, Foreign Law and Theoretical Authority, "Global Constitutionalism" 2016, Vol. 5(1), p. 90.

${ }_{31}$ J. Raz, The Authority of Law, p. 8; L. Green, The Authority of the State, Oxford University Press, 1988, p. 27. Even though there is significant agreement in legal literature on this subject, the exact differences between theoretical and practical authority are not uncontroversial. Heidi Hurd believes that all kinds of epistemic authority function evidentially, they give us "reasons to think 


\section{Practical authority of precedents}

In order to explain both epistemic and practical authority, we thus have to dive into an analysis of reasons, for our reasoning is determined by the kinds of reasons that utterances of authorities give rise to. Practical authorities issue orders and orders are qualitatively different from both advise and requests. The idea behind an order issued by an authority is not to simply impact the balance of reasons by giving us weighty reasons for action but to give us a reason that excludes the first-order reasons for acting contrary to the order ${ }^{32}$. In order to understand practical authority issuing orders we, thus, have to employ not just the idea of first-order reasons but also the idea of second-order reasons. The role of second-order reasons in practical reasoning can either be a reason to act on first-order reasons (positive second-order reasons) or a reason not to act on first-order reasons (negative second-order reasons or exclusionary reasons) ${ }^{33}$. A combination of first order reasons and second order exclusionary reasons is called by J. Raz a protected reason. The ability to give rise or to change protected reasons is normative power, and practical authority is one kind of normative power. In the most general sense, we could therefore say that someone or something has practical authority iff its utterances are protected reasons for action ${ }^{34}$.

This helps us to clarify the authority of precedents in various legal systems. Judicial reasoning in common law countries is in great part based on adjudicative precedents. A previous judicial decision is considered to be a formal source of law, and the norms that have been established by the source of law have the status of

that there are other reasons to act as recommended" (see: H.M. Hurd, op. cit., p. 63). What follows is that the utterances of an epistemic authority are content dependent reasons for action, or, more rigorously formulated: " $X$ has epistemic authority for $Y$ if and only if, as a result of $X$ 's stating that $Y$ ought to do act $A, Y$ has a reason to believe that the balance of (content-dependent) reasons dictates that $Y$ ought to do $A$ ". On this account, an utterance of an epistemic authority merely makes more probable that we should act in accordance accordingly, since it only points us to other antecedent reasons to act in a certain manner. This applies of course only on deontic propositions, and not on beliefs in general, and may be sound in situations in which an epistemic authority utters deontic propositions. Still, even in those cases it is not clear what makes a person who tells us what to do an authority, even an epistemic authority, if he doesn't give us new reasons for belief, and the reasons for belief that he gives us are content dependent. If we can call something or someone an authority it seems necessary that it's utterances are authoritative in virtue of their source and not in virtue of their content. Influential authority and practical authority would, in this line of thought, provide for new reasons to act. Those reasons would be content independent. See: ibidem, p. 65. While it could be that theoretical authorities can give us content dependent reasons for action by giving us content independent reasons for belief, this is certainly not a core feature of epistemic authorities.

32 J. Raz, The Authority of Law, p. 18.

${ }^{33}$ Heidi Hurd notices that it is pretty hard to come up with every day examples in which someone gives us exclusionary reasons for action. See: H.M. Hurd, op. cit., pp. 73-75.

34 J. Raz, The Authority of Law, p. 29. 
practical authority. This basically means that precedents are protected reasons for action - they give a reason to decide in accordance with the precedent (or a rule exemplified by the precedent) and exclude the first-order reasons that we might have for deciding in another way ${ }^{35}$. The status of precedents as protected reasons for action in civil-law systems is determined by the regulation of their status in main sources of law - namely statutes and the constitution. So, if precedents are formal sources of law, their authority is of a practical kind - they give judges protected reasons for action. Both precedents of interpretation and precedents of solution can be formally binding in civil-law systems - interpretative decisions, as well as decisions of a case, can be explicitly legislated as sources of law within a legal system, or they can be considered binding under a rule of recognition by the courts. As such they could give legal officials, mainly judges, protected reasons for action - a reason to decide a case in a certain way, or a reason to ascribe a specific meaning to a legal text regardless of other reasons that they might have for deciding the case in a different way. Furthermore, these reasons for action are specifically legal - judges and officials in general are expected to ascribe a meaning because the meaning has been prescribed by law.

The character of precedents of adjudication and precedents of interpretation under the condition of formal bindingness is even here somewhat different. As explained in the previous part there is significant debate about what is binding in a decision that represents a precedent of solution - is the decision itself binding or the rule that the decision was based on. When it comes to precedents of interpretation the matter is somewhat simpler. Their role is like the role of definitory norms in statutes. Interpretative precedents are ascriptions of meaning that give protected reasons to ascribe the same meaning to the legal text. They are protected reasons insofar as they are formally binding for the courts. Inquiries into the power of precedents in systems with long and stable civil law traditions have concluded "the normativity of precedent has evolved as a matter of judicial practice and marks the emergence of a new type of accepted legal authority in civil law countries beyond constitution, code, statute and administrative regulation or decree, and even beyond hierarchical reversibility" ${ }^{\prime 3}$. Let me mention a few examples of interpretative precedents as formal sources of law, derived from recent studies of the role of precedents in legal systems in Central and Eastern Europe: The Organic Law on Common Courts in Georgia from 2009 states that "legal interpretations (interpretation of a norm) by the Grand Chamber of the Supreme Court shall be binding upon the common courts of all instances"; The Ukrainian Law on the Judiciary and the Status of Judges from 2010 prescribes that "the decision of the Supreme Court of Ukraine [...] is binding for all subjects of authority that apply in their activities

${ }^{35}$ The status of precedents in these cases is they are binding regardless of the judge's current beliefs about the previous decision that acts like a precedent. See: F. Schauer, Precedent, p. 576.

${ }^{36}$ N. MacCormick, R. Summers, Further General Reflections and Conclusions, p. 533. 
normative legal act that contains the specified legal norm, and for all courts of Ukraine"; The Law on Courts of Lithuania in Article 31 mandates that the "state and other institutions, as well as other persons, shall apply the interpretations of laws, regulations and administrative provisions contained in decisions and rulings of the Supreme Administrative Court applying the same laws and regulations"37.

All these statutory norms establish precedents of interpretation as formally binding. In every one of these case and interpretative decision is a protected reason for action in the following simple sense - a court interpreting the law might have some first-order reasons to ascribe a meaning to a legal provision, but the ascription of meaning to the same provision by the Supreme Court is an exclusionary reason for ascribing another meaning to the provision ${ }^{38}$.

\section{Epistemic authority of precedents}

It is commonly thought that it is justified, or morally required by principles of political legitimacy in contemporary states, to interpret the law in a consistent manner. This requirement of uniformity of interpretation is emphasised by legal scholarship even in jurisdictions in which the primacy of statutes renders overt appeals to precedents, even to interpretative precedents, as unnecessary ${ }^{39}$. For no matter the issue of formal bindingness, "the reasons that judges provide for the decisions that they reach $[\ldots]$ have directive force" ${ }^{40}$.

37 The examples are based on the presentation entitled "Case Law of Supreme Courts in Post-Soviet Legal Systems" given by Nazar Stetsyk on the occasion of the Annual Conference of the Central and Eastern European Network of Jurisprudence (CEENJ organized by the University of Latvia on September 15-16, 2017).

${ }^{38}$ Precedents can also give non-exclusionary prudential reasons for action. In this sense, they are binding as a matter of law in civil-law jurisdictions, even if it is not a part of the constitution or statutes (see: N. MacCormick, R. Summers, Further General Reflections and Conclusions, p. 533). The relative position of one judge in relation to the other in a hierarchy, and the position of one court in relation to the other, makes many adjudicative and interpretative decisions subject to review. A lower court will have prudential reasons follow the decisions of the higher court, when the structure of the system of courts allows the higher court to reverse or invalidate the decisions of the lower court. In this way, the decisions of higher courts will serve as a model for the reasoning of lower courts, as the authoritative position of a higher court is procedurally established. A recent detailed discussion of practical authority can be found in: K.E. Himma, Morality and the Nature of Law, Oxford University Press, forthcoming 2018.

${ }^{39}$ M. Troper, Ch. Grzegorczyk, op. cit., p. 126. Troper mentions some of the arguments that make the appeal to interpretative precedents necessary according to French scholars. One is the requirement of treating similar cases similarly even in terms of interpretation of relevant statutory provisions. The other is the epistemic requirement that if an interpretation of a statute is thought to be correct, this cant vary from case to case, but has to apply to future interpretations. Ibidem.

${ }^{40}$ N. Duxbury, op. cit., p. 48. 
Interpretative precedents in this sense are a mechanism for correcting some of the issues that are necessarily present in the regulation of behaviour with enactments containing general language. If general language is inherently indeterminate, and the legal system doesn't contain the means of eliminating the indeterminacy, judicial interpretative reasoning will necessarily include previous ascriptions of meaning as cornerstones for their reasoning, even without explicit acknowledgment.

Most interpretative precedents, without legal or prudential reasons to follow them, will have influence or persuasive force for the subsequent authoritative interpreters of legal texts. This practically means that a precedent will give the judge a first-order reason to believe that a provision should have the meaning that was previously ascribed to it by a court. If the force of the precedent is considered simply to be persuasive, then the precedent is weighed with other first-order reasons for believing that a different meaning should be ascribed to a provision. For example, a court could have reasons to interpret the word 'family' to mean "life union between two persons that lasts for a longer time". A previous interpretation of another court could say that "family" includes the unions between two persons that lasted for a day, as long as there was conclusive evidence that they were planning to form a lasting union. The interpretation could be persuasive for the other courts, in the sense that they would weigh the previous interpretation against all of the other reasons for interpreting the word 'family' in the same way.

Interpretative precedents are often considered to be epistemically authoritative and not only persuasive. Whenever a judge or a group of judges believe that a provision or part of a provision means what a previous court claimed that it means, because a previous court claimed that the provision means that, the previous court is treated as an epistemic authority. Let me briefly explain the notion of epistemic authority. Our reliance on the opinions of others in many areas of knowledge is ubiquitous. We are often inclined to take the opinions of other persons as reasons for holding those same opinions, just because they are held by persons that possess some qualities that make their opinion trustworthy. We tend to treat the opinions of other persons that possess relevant knowledge or skills as reasons for belief. The authority of those persons is an epistemic authority ${ }^{41}$. The most common way of thinking about an epistemic authority is to view it as a kind of expertise; we say that a practicing lawyer has epistemic authority in the domain of litigation in civil

${ }^{41}$ From the perspective of contemporary epistemology and social epistemology epistemic authority could be treated as a subsection of testimony and testimonials based belief. This would however depend on the definition of testimonial belief. One of the prominent positions on testimony is the claim by Elizabeth Fricker that testimony is connected with telling in general. See: J. Lackey, Introduction, [in:] The Epistemology of Testimony, eds. J. Lackey, E. Sosa, Oxford University Press, 2017 , p. 2. The basic characteristics of authority and epistemic authority could be enough to delimitate it in the field of testimony in general, as we are not interested in any inquiry into knowledge based on what other people tell us, but only insofar as it gives us content independent reasons for belief. 
or criminal suits, or that a medical doctor has epistemic authority when it comes to common illnesses ${ }^{42}$. An expert is a person that is epistemically in a better position than the other person to "have, or make a judgement to form a conscious belief" regarding something ${ }^{43}$. Whenever a judge or court forms a belief about meaning of a word or provision because of a previous judicial ascription of meaning to the same word or provision, the judge or court treats the previous decision-maker as an epistemic authority. Interpretative precedents have, therefore, the possibility of being not just practically authoritative, but also epistemically authoritative.

Interpretative ascriptions of meaning are often in fact epistemically authoritative even if they are not practically authoritative. If they are considered to have epistemic authority they give content independent reasons for belief but not for action. In cases in which a judge believes interpretation of another court just because it is the interpretation of another court, we say that the previous interpretation has epistemic authority. This is the nature of claims about meaning originating not only from other courts but also from legal doctrine, legal science, and legal theory and philosophy. There is a further epistemic issue here though. A judge could unjustifiably take the ascription of meaning of another court to be authoritative, without good reason for doing so. The question in the next part of the paper is what are the conditions for an interpretative precedent to have legitimate epistemic authority.

\section{JUSTIFICATION OF REASONING WITH PRECEDENTS}

Classical writing on precedent in common-law emphasised the idea that precedential reasoning is a requirement of rationality. Both Edward Coke and Matthew Hale wrote about the connection between rationality and coherence in regards of precedential reasoning ${ }^{44}$. A long-standing project of Gerald Postema is to prove that precedents, even when they are not formally binding for judges, were thought to "exemplify proper legal reasoning" 45 .

${ }^{42}$ Hans-Georg Gadamer devotes most of his discussion about authority to derivative epistemic authority and writes: "It is primarily persons that have authority; but the authority of persons is ultimately based not on the subjection and abdication of reason but on an act of acknowledgment and knowledge - the knowledge, namely, that the other is superior to oneself in judgment and insight and that for this reason his judgment takes precedence - i.e., it has priority over one's own". See: H.-G. Gadamer, Truth and Method, Continuum, 2006, p. 281.

${ }^{43}$ E. Fricker, Testimony and Epistemic Autonomy, [in:] The Epistemology of Testimony, eds. J. Lackey, E. Sosa, Oxford University Press, 2006, DOI: https://doi.org/10.1093/acprof:oso/9780199276011.003.0011, p. 233.

${ }_{44}^{4}$ N. Duxbury, op. cit., pp. 48-49.

${ }^{45}$ Ibidem, p. 51. 
Following precedents is commonly thought to be justified for reasons of justi$c e$, which would encompass the necessity of treating like cases alike. The second ground for justification is predictability, understood as the possibility of everyone to anticipate the decision of the court. The third value is efficiency, since relying on precedents can relieve a court from the burden of deliberating endlessly about every aspect of the case ${ }^{46}$. From a moral perspective, and perhaps in a less persuasive fashion for the standards of legal thinking, G. Postema argues that precedents are based on faith of members of a community in that community and to each other ${ }^{47}$.

Every one of those arguments has their strengths and weaknesses, and it could be argued that reasoning with precedents aids in the realization of these values within a legal system ${ }^{48}$. I will, however, concentrate on the possibility of epistemically justifying both precedents of solution and precedents of interpretation.

\section{Epistemic justification of precedents of solution}

The idea that precedents of solution are can be epistemically justified is today questioned on the following grounds: it is not enough that precedents give us reasons for belief but reasons for action. Epistemic justification is directed at our belief that a precedent was the correct solution of a case, and doesn't do much in justify the decision. Deborah Hellman correctly notes "the justification of genuine precedential reasoning can be epistemic in nature" ${ }^{49}$. I'll confine myself to presenting the epistemic arguments put forward by D. Hellman.

There are, according to D. Hellman, two epistemic arguments that appraise the value of precedents within a legal system. The first is procedural: we have good reasons to think that a system with stare decisis in place puts the burden of giving reasons for departing from precedents on the judge, and it forces the judge to step out of his narrow personal perspective ${ }^{50}$. In this way, a system that introduces some constraint on judges by precedents of solution is more likely to yield better decisions. The second argument is substantive and it rests on the claim that precedents are not simple decisions, but decisions based on a process of reasoning in different time periods, that "yield superior judgement than would the decision of any particular person or group today" 51 .

${ }^{46}$ F. Schauer, Precedent, pp. 595-601.

${ }^{47}$ G.J. Postema, op. cit., p. 1178.

48 See: A.T. Kronman, op. cit., pp. 1037-1040.

49 D. Hellman, An Epistemic Defence of Precedent, [in] Precedent in the United States Supreme Court, ed. Ch.J. Peters, Springer Publishing, 2014, p. 66.

${ }^{50}$ Ibidem, p. 71.

${ }^{51}$ Ibidem. 


\section{Epistemic justification of precedents of interpretation}

Just like the basing of decisions of solution on whatever reasons would lead to inconsistencies within a legal system, and would be highly inefficient, making interpretative decisions without regard for previous interpretative decisions would be inconsistent and even wasteful in the sense that every ascription of meaning would imply an all things considered decision. But is a court ever rationally justified to defer to an interpretation of a court that previously interpreted the provision?

One of the most prominent features of contemporary legal systems is that they regulate human behaviour by using general classifying terms. The tools for making known the rules and principles containing general classifying terms are most commonly statutes ${ }^{52}$. General classifying terms that are used in statutes are in various ways indeterminate. One common mode of reducing the indeterminacy are rules, cannons, maxims of interpretation, which are useful insofar as they narrow the options in terms of ascribing meaning to the legal text. The amount of indeterminacy is nowadays often mitigated by specific rules that prescribe which meaning should be ascribed to words in statutes - there has been in recent times a proliferation of definitory norms in statutory texts. Precedents of interpretation are one way of reducing the indeterminacy of rules communicated by general classifying terms that is related to modes of reasoning that are characteristic for reasoning with precedents. Precedents, as a mode of reasoning, are in fact constraining for interpretation ${ }^{53}$, in ways in which statutes are not.

We don't reach knowledge by personally examining every piece of evidence available to man, and by using only our senses and faculties. Most of our beliefs are based on the fact that we were, at one point or another told that a proposition is correct. If this proposition was uttered by a de facto epistemic authority, we can in principle and prima facie, have reasons to believe that the proposition is true or correct, even if we don't really on personally examined reasons. Just consider some simple things that we consider as facts, that can only be justifiably believed by relying of utterances of epistemic authorities, and in no other way. Such are many undocumented things from the first years of our life that were told to us by our parents. This prima facie reliance on opinions of other persons in general, and epistemic authorities in particular and can be found in all fields of human knowledge, even in natural science ${ }^{54}$. It is enough to ask oneself what are reasons to believe that the theory of evolution or general relativity is true. In this sense, it

${ }^{52}$ H.L.A. Hart, The Concept of Law, Clarendon Press, 1994, p. 124.

${ }_{53}^{3}$ N. Duxbury, op. cit., p. 11.

${ }^{54}$ A recent paper about the size of Higgs boson was co-authored by 5154 people, see: www. nature.com/news/physics-paper-sets-record-with-more-than-5-000-authors-1.17567 [access: 10.02.2018]. For discussions about epistemic dependence and epistemic authority in science see: J. Hardwig, Epistemic Dependence, "The Journal of Philosophy" 1985, Vol. 82(7), DOI: https://doi. 
can be claimed that "continuity with the past", which reasoning with precedents instantiates, "is not a duty, it is only a necessity" 55 .

Moving to the field of legal interpretation and adjudication, legally authoritative meanings of legal texts are for all intents and purposes significantly dependent on beliefs of judges within a legal system. Those shared beliefs are formed within a community of lawyers. The relation between members of this community are often not the relations of epistemic peers. The complexity of contemporary legal systems doesn't allow for specialised knowledge in every single field of law. This is even acknowledged formally in all of the cases in which courts summon experts in a field of legal study, rely on interpretations of courts on the international level or courts from other jurisdictions, invoke commentaries of statutes and codes to justify their interpretations etc. In all of these cases, the relevant subjects are treated as epistemic authorities by the courts.

The authority of interpretative precedents over belief is thus a special case of epistemic authority. A court adjudicating an issue related to any general classifying term that allows for multiple ascriptions of meaning has good epistemic reasons to ascribe the meaning that was ascribed in the previous decisions for those interpretations are based on a countless number of cases. The general formula of justified deference to interpretative precedents could, therefore, be formulated in the following way: whenever a court that interpreted the provision has more knowledge, experience or practice in interpretation of statutory texts it is prima facie epistemically justified to defer to the interpretative ascription of that court.

\section{CONCLUSIONS}

Civil-law courts use previous judicial decisions as models in their reasoning. The previous judicial decisions that serve as a model for future decisions are precedents. Precedents play a significant role not only and not exclusively in deciding future cases but also in interpreting statutory and constitutional provisions. In other words, precedents do not serve as models when reaching a decision about a case, but also when reaching a decision about the meaning of a provision. In systems in which precedents of solution or precedents of interpretation are formal sources of law, they are treated as having practical authority, giving courts content-independent reasons for action. In systems in which precedents of interpretation are not formal sources of law, they can be treated as having epistemic authority, giving judges content-independent reasons to believe that a previous interpretation is correct.

org/10.2307/2026523, pp. 334-349; idem, The Role of Trust in Knowledge, "The Journal of Philosophy” 1991, Vol. 88(12), DOI: https://doi.org/10.2307/2027007, pp. 692-708.

55 O.W. Holmes, The Collected Legal Papers, Courier Corporation, 2012, p. 139. 
Since legal knowledge based on testimony and epistemic authority permeate in our interpretations of law, without earlier judicial interpretations it is difficult to imagine a functioning legal system reliant entirely on legislative action, at least if legislative action consists of enacting general legal provisions. Insofar as we agree that general rules do not fully determine the entirety of reasonable outcomes of adjudicating according to those rules, we are, it seems to me, compelled to say that without epistemic authority of precedents we cannot have a legal system that functions in a manner that is predictable to those who are subject to it. Treating interpretative precedents as having epistemic authority is rationally justified under the condition that the precedent was set by a judge or court with more knowledge, experience or practice in the interpretation of the relevant provision.

\section{REFERENCES}

Alexander L., Constrained by Precedent, "Southern California Law Review" 1989, Vol. 63(1).

Doyle O., Constitutional Cases, Foreign Law and Theoretical Authority, "Global Constitutionalism" 2016, Vol. 5(1).

Duxbury N., The Nature and Authority of Precedent, Oxford University Press, 2010.

Dworkin R., Taking Rights Seriously, Harvard University Press, 1977.

Flanders C., Toward a Theory of Persuasive Authority, "Oklahoma Law Review" 2009, Vol. 62(1).

Foley R., Intellectual Trust in Oneself and Others, Cambridge University Press, 2001,

DOI: https://doi.org/10.1017/CBO9780511498923.

Fricker E., Testimony and Epistemic Autonomy, [in:] The Epistemology of Testimony, eds. J. Lackey, E. Sosa, Oxford University Press, 2006,

DOI: https://doi.org/10.1093/acprof:0so/9780199276011.003.0011.

Gadamer H.-G., Truth and Method, Continuum, 2006.

Glenu H.P., Persuasive Authority, "McGill Law Journal” 1987, Vol. 32(2).

Green L., The Authority of the State, Oxford University Press, 1988.

Hardwig J., Epistemic Dependence, "The Journal of Philosophy" 1985, Vol. 82(7),

DOI: https://doi.org/10.2307/2026523.

Hardwig J., The Role of Trust in Knowledge, "The Journal of Philosophy” 1991, Vol. 88(12),

DOI: https://doi.org/10.2307/2027007.

Hart H.L.A., The Concept of Law, Clarendon Press, 1994.

Hellman D., An Epistemic Defence of Precedent, [in] Precedent in the United States Supreme Court, ed. Ch.J. Peters, Springer Publishing, 2014.

Himma K.E., Morality and the Nature of Law, Oxford University Press, forthcoming 2018.

Holmes O.W., The Collected Legal Papers, Courier Corporation, 2012.

Hurd H.M., Moral Combat, Cambridge University Press, 1999,

DOI: https://doi.org/10.1017/CBO9780511896880.

Kronman A.T., Precedent and Tradition, "The Yale Law Journal” 1990, Vol. 99,

DOI: https://doi.org/10.2307/796595.

Lackey J., Introduction, [in:] The Epistemology of Testimony, eds. J. Lackey, E. Sosa, Oxford University Press, 2017.

Lukes S., Power, Palgrave Macmillan, 2005, DOI: https://doi.org/10.1007/978-0-230-80257-5.

MacCormick N., Summers R.S., Further General Reflections and Conclusions, [in:] Interpreting Precedents, eds. N. MacCormick, R.S. Summers, Routledge, 1997. 
MacCormick N., Summers R.S., Introduction, [in:] Interpreting Precedents, eds. N. MacCormick, R.S. Summers, Routledge, 1997.

Marmor A., Social Conventions, Princeton University Press, 2009,

DOI: https://doi.org/10.1515/9781400831654.

Merriam-Webster Dictionary, www.merriam-webster.com/dictionary/precedent [access: 10.02.2018].

Peczenik A., Scientia Juris: Legal Doctrine as Knowledge of Law and as a Source of Law, Springer Publishing, 2005.

Postema G.J., On the Moral Presence of Our Past, "McGill Law Journal” 1991, Vol. 36(4).

Raz J., Practical Reason and Norms, Oxford University Press, 1999,

DOI: https://doi.org/10.1093/acprof:oso/9780198268345.001.0001.

Raz J., The Authority of Law, Oxford University Press, 1979.

Raz J., The Morality of Freedom, Oxford University Press, 1988,

DOI: https://doi.org/10.1093/0198248075.001.0001.

Schauer F., Authority and Authorities, "Virginia Law Review" 2008, Vol. 94.

Schauer F., Precedent, "Stanford Law Review" 1987, Vol. 39(3),

DOI: https://doi.org/10.2307/1228760.

Schauer F., Profiles, probabilities, and stereotypes, Harvard University Press, 2003.

Summers R.S., Departures from Precedents, [in:] Interpreting Precedents, eds. N. MacCormick, R.S. Summers, Routledge, 1997.

Troper M., Grzegorczyk Ch., Precedent in France, [in:] Interpreting Precedents, eds. N. MacCormick, R.S. Summers, Routledge, 1997.

Zagzebski L.T., Epistemic Authority, Oxford University Press, 2012.

\section{STRESZCZENIE}

W artykule omówiono teoretycznoprawne aspekty wpływu precedensów na praktykę stosowania prawa w systemach prawnych należących do kręgu civil law jako modelu przyszłych decyzji prawnych. W tym kontekście analizie poddano samo pojęcie precedensu i wskazano różnice pomiędzy precedensem decyzyjnym i interpretacyjnym. Na gruncie tych ustaleń prowadzone są rozważania dotyczące źródeł ,,autorytetu” precedensu oraz podstaw i sposobu jego wpływu na późniejsze orzeczenia. W efekcie prowadzi to do wyodrębnienia i dostrzeżenia specyfiki praktycznego i epistemicznego ujęcia oraz uzasadnienia autorytetu precedensu.

Słowa kluczowe: precedens; autorytet precedensu; praktyka precedensowa 